\title{
Methodology for the construction of an urban flood hazard chart
}

\section{Metodologia para construção de gráfico de risco de inundações urbanas}

\author{
Rejane Cristina Siqueira ${ }^{1,2}$, Priscilla Macedo Moura $^{1}$ (D) and Talita Fernanda das Graças Silva ${ }^{1}$ (D) \\ ${ }^{1}$ Programa de Pós-graduação em Saneamento, Meio Ambiente e Recursos Hídricos, Departamento de Engenharia Hidráulica e Recursos Hídricos, \\ Universidade Federal de Minas Gerais, Belo Horizonte, MG, Brasil \\ ${ }^{2}$ Diretoria de Gestão de Águas Urbanas, Prefeitura de Belo Horizonte, Belo Horizonte, MG, Brasil \\ E-mails: rejanehadassa@yahoo.com.br (RCS),priscilla.moura@ehr.ufmg.br (PMM), talita.silva@ehr.ufmg.br (TFGS)
}

Received: July 24, 2018 - Revised: February 26, 2019 - Accepted: March 20, 2019

\begin{abstract}
Flood events are one of the major causes of economic loss and the loss of life worldwide. Unfortunately, their occurrence has become increasingly more frequent and of greater magnitude. In order to minimize the population's exposure to danger, it is necessary to invest in tools that aid in the decision-making process related to urban drainage management. The present work proposes a methodology for the construction of a Flood Hazard Chart for urban watersheds. The Storm Water Management Model (SWMM) was applied to the Cachoeirinha Watershed (Belo Horizonte, Brazil). The model was calibrated and validated using precipitation data and water levels recorded in monitoring stations located in the study area. The Nash-Sutcliffe Coefficients for the calibration and validation were 0.72 and 0.70 , respectively. The performance of the model was satisfactory, although the model was not able to represent the more intense rain events that led to emergency and overflow warnings. Modeling results allowed the construction of the hazard chart, which defined hazard ranges or warning levels of hazard as a function of accumulated rainfall and duration. The constructed graph was assessed from real precipitation events and proved to be valid, since most events corresponded with the defined warning levels in the chart. The Flood Hazard Chart proposed in this research is a valuable tool for flood risk management as it has the potential to reduce exposure to flood disasters.
\end{abstract}

Keywords: Flood hazard management; Hydrological Modeling; SWMM; Urban drainage.

\section{RESUMO}

Os eventos de inundação são uma das principais causas de prejuízos econômicos e de perdas de vidas humanas em todo o mundo. Infelizmente, a sua ocorrência tem se tornado cada vez mais frequente e de maior magnitude. Para minimizar os riscos aos quais a população está exposta, torna-se necessário investir em ferramentas que auxiliem no processo de tomada de decisão relativo à gestão da drenagem urbana. O presente trabalho propõe uma metodologia para construção de gráfico de risco de inundação em bacias urbanas. Para tanto, foi aplicado o modelo Storm Water Management Model (SWMM) na bacia do Córrego Cachoeirinha (Belo Horizonte, Brasil), calibrado e validado com dados de precipitação e níveis d'água registrados em estações de monitoramento. Nas etapas de calibração e validação obteve-se, respectivamente, Coeficiente de Nash-Sutcliffe igual a 0,72 e 0,70. Dessa forma, pode-se considerar o desempenho do modelo satisfatório, ainda que o mesmo não tenha representado bem os eventos chuvosos mais intensos que geraram alertas de emergência e extravasamento do canal. Os resultados da modelagem possibilitaram a construção do gráfico de risco, que definiu faixas de risco ou níveis de alerta de risco em função do volume de chuva acumulada e da duração da mesma. O gráfico construído foi avaliado a partir de eventos reais de precipitação e demonstrou-se válido, uma vez que os eventos, em sua maioria, se ajustaram aos níveis de risco definidos. O gráfico de risco de inundações é uma valiosa ferramenta para a gestão do risco de inundações uma vez que pode reduzir a exposição da população a tais eventos.

Palavras-chave: Gestão de risco de inundação; Modelagem hidrológica; SWMM; Drenagem urbana. 


\section{INTRODUCTION}

Among all of the natural disasters, including avalanches, landslides, drought/scarcity, earthquakes, epidemics, volcanic activity, and windstorms, flooding is the most frequently occurring; in addition, the number of events has considerably increased in recent years worldwide (Europe - DOTTORI et al., 2016; China - JIA et al., 2018; Brazil - LIMA; AMORIM, 2014; MENEZES FILHO; AMARAL, 2014). For most of the last century, managers and engineers sought to protect cities from flood events through structural flood control measures in rivers and streams. Despite these heavy investments, the damage caused by flooding has continued to increase; thus, from the early 1990s on, a new approach to deal with these disasters has been adopted: flood risk management (SAYERS et al., 2015).

The risk of flooding may be defined in several ways, but in general, it encompasses the probability of flooding (hazard) and the associated consequences to the occurrence of this event (SAYERS; HALL; MEADOWCROFT, 2002). The hazard is the occurrence probability of the rain event that generates the flood, which is also related to the probability of the water arriving at a certain point in the floodplain. The consequences depend on the exposure and vulnerability to the flood event of a given receptor, such as a person, buildings, or infrastructure. The exposure quantifies affected people, buildings, fauna, and flora, while the vulnerability describes the potential of a given receptor to suffer damage (SAYERS et al., 2013). In this context, flood risk management is an approach that reduces not only the probability of flooding, traditionally handled through structural measures, but also the damage associated with the event occurrence. The damage may be minimized by reducing exposure through forecasting and flood warning systems. Helping those affected by flooding to recover is an alternative for reducing vulnerability (SAYERS et al., 2015). Flood risk management, as opposed to traditional flood control, can be seen as a continuous process that attempts to use the limited resources of time, social and environmental efforts, and capital to achieve multiple benefits (SAYERS et al., 2013).

According to the World Resources Institute (WRI, 2015), among the 15 countries most affected by flood events, which include $80 \%$ of the exposed population around the world, Brazil occupies the 11th position. In Brazil, the inefficiency of urban development and land use planning policies has led to the occupation of riverside areas, increased surface imperviousness, and the channelization of rivers and streams (TUCCI; CRUZ, 2008). As a result, flooding episodes in urban and riverside areas have intensified and become more frequent in recent decades (TUCCI; BRAGA, 2003; MENEZES FILHO; AMARAL, 2014).

In this context, the application of tools to aid in decision-making processes for flood risk management has become increasingly important (MELLER; PAIVA, 2007). Forecasting models, floodplain mapping, flood-damage curves, and flood insurance are examples of flood management tools currently in use. The current research presents a methodology for the development of a hazard chart constructed from design rainfall and the outputs of hydrological and hydraulic modelling. This Flood Hazard Chart provides information on the possibility of overflow in rivers and channels depending on rain volume and duration.
The Flood Hazard Chart integrates weather forecasting information and/or real-time precipitation data, enabling faster warning emissions for floodable areas. The celerity in the transmission of flood warnings is especially vital in tropical urban watersheds, areas subject to pluvial floods, and areas located upstream of watersheds. Such areas are exposed to very intense, short-duration rain events, notably due to convective rains. The hydrological response in these catchments often occurs within a short time, ranging from a few minutes to half an hour.

Integrating high-resolution and real-time hydrological and hydrodynamics modeling with warning systems is increasingly tangible thanks to advances in remote sensing, geoprocessing, computing software, and hardware. However, high computational time for simulations and the need for high spatial and temporal resolution data still represent a challenge for this integration in flood risk management (RENÉ et al., 2014). This challenge is even greater in Brazil, where most municipalities lack specialized technical staff, such as hydrologists and meteorologists.

Szewrański et al. (2018) affirm that there are several gaps in the knowledge and research pertaining to the modeling, risk assessment, and risk management of pluvial floods. Studies evaluating the hazards and damage resulting from pluvial floods are less common than those referring to river floods. Moreover, there are no consistent or commonly employed methodologies for the assessment and mapping of pluvial flood risk. Thus, the Flood Hazard Chart proposed in this research is a valuable tool for flood risk management as it has the potential to reduce exposure to flood disasters.

This article is divided into two parts. The first section presents a methodological proposition for the construction of the Flood Hazard Chart. The second section includes a case study in which a Flood Hazard Chart is constructed and assessed for the Cachoeirinha watershed in Belo Horizonte/MG (Brazil).

\section{METHODOLOGY FOR FLOOD HAZARD CHART CONSTRUCTION}

The proposed methodology is divided in four steps (Figure 1), namely: (1) watershed data collection; (2) hydrological and hydraulic modeling, including sensitivity analysis, model calibration and validation; (3) the Flood Hazard Chart construction; (4) performance assessment of the Flood Hazard Chart.

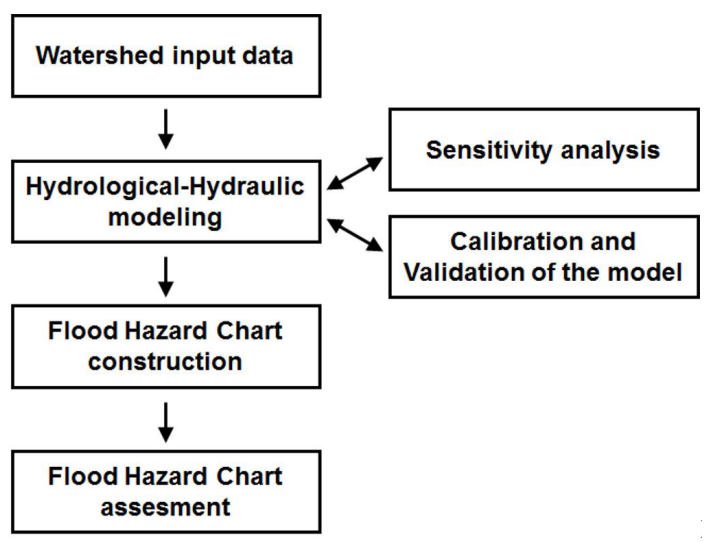

Figure 1. Methodology main steps. 


\section{Watershed data}

The watershed data include:

- Hydrological data: precipitation, flow rates, and/or water level, rating curve;

- Physiographic data: catchment area, width, slope, imperviousness;

- Land use and cover and soil type;

- Drainage infrastructure inventory: available registers, topographic map.

\section{Hydrological and hydraulic modeling}

Currently, there are several hydrological and hydraulic models available; Zoppou (2001), Fletcher, Andrieu and Hamel (2013), as well as Salvadore, Bronders and Batelaan (2015), present a comprehensive review of the existing models most commonly found in studies of hydrological and hydraulic modeling in urban areas. The model choice depends on the study objectives, spatial resolution, data variability, available technology, and the modeler experience. In addition, data availability should be considered, since more complex models require more precise watershed information (SALVADORE; BRONDERS; BATELAAN, 2015).

One of the most widely used models in urban drainage modeling is the Storm Water Management Model (SWMM) (ROSSMAN, 2004; LENHS, 2012), which couples hydrological and hydraulic modeling (NIAZI et al., 2017). This is a public domain software with open-source programming code. In many scientific studies developed in Brazilian catchments, SWMM presented satisfactory results (ZANANDREA; SILVEIRA, 2018; SILVA et al., 2016; SOUZA; CRISPIM; FORMIGA, 2012).

Once the hydrologic-hydraulic model is selected, the model performance criteria are chosen. Then, the sensitivity analysis and the model calibration and validation are performed.

\section{Model performance criteria}

The model calibration depends on the assessment of the errors between the observed data and the modeling results. Such errors can be quantified through objective functions that assess the model's performance. Calibrating model parameters means finding the parameter vector that minimizes one or more objective functions (TUCCI, 2005).

The Nash-Sutcliffe model efficiency coefficient (COE, Equation 1) is often applied in the performance assessment of hydrological models (BENNETT et al., 2013).

$$
C O E=1-\frac{\sum_{i=1}^{N}(O i-P i)^{2}}{\sum_{i=1}^{N}(O i-\bar{O})^{2}}
$$

where: $\mathrm{Oi}=$ observed value; $\mathrm{Pi}=$ simulated value; $(\bar{O})=$ mean of observed values; $\mathrm{N}=$ number of observations.

The COE indicates how well the model explains the variance in the observations when compared to the use of its mean value.
A value of 1 indicates a perfect model, while negative values indicate that the model's performance is worse than simply using the mean of the observed values. According to Collischonn (2001), for COE values greater than 0.75 , model performance is good; for COE values between 0.36 and 0.75 , model performance is acceptable; and $\mathrm{COE}$ values lower than 0.36 indicate an unacceptable model. Other authors indicate various ranges of values; for example, Pfannerstill, Guse and Fohrer (2014) adopted COE values below 0.25 as unsatisfactory, between 0.25 and 0.7 as acceptable, and above 0.70 as good.

Other objective functions can be used to assess the modeling results, such as the Root Mean Square Error (RMSE, Equation 2) and the relative error (Error\%, Equation 3). The RMSE is a non-normalized metric that expresses the model performance in the same unit as the data; the higher its value, the lower the model's ability to represent observed data. Error \% varies between 0 and 100 , and higher values indicate poorer performance.

$$
\begin{aligned}
& \text { RMSE }=\sqrt{\frac{1}{N} \sum_{i=1}^{N}\left(O_{i}-P_{i}\right)^{2}} \\
& \text { Erro } \%=\left(\frac{O_{i}-P_{i}}{O_{i}}\right) \times 100
\end{aligned}
$$

where: $\mathrm{Oi}=$ observed value; $\mathrm{Pi}=$ simulated value; $\mathrm{N}=$ number of observations.

In hydrological modeling, COE is usually used to compare simulated and observed hydrographs while RMSE and Error\% are often used to assess the model's ability to predict hydrological parameters, such as peak flows, lag time, recession time, and runoff volume (PFANNERSTILL; GUSE; FOHRER, 2014).

\section{Sensitivity analysis}

Through sensitivity analysis, it is possible to verify which model parameters have little or no influence on the results and, therefore, require little or no calibration effort. Sensitivity analysis can be performed manually through a one-at-a-time method. First, the initial values of the model parameters should be defined based on the literature and the modeler experience. Then, the value of each parameter is changed individually while the others remain fixed. The results are assessed through an objective function, such as a COE.

Based on the minimum and maximum COE values, the model's sensitivity to the parameters can be computed through a Sensitivity Index (I.S). Loucks and Van Beek (2005) propose (Equation 4):

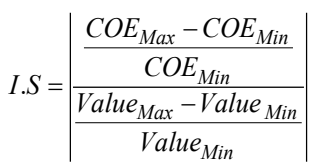

where: Value ${ }_{\text {Min }}$ and Value $_{\text {Max }}$ are, respectively, the minimum and maximum values of the parameter, and $\mathrm{COE}_{\mathrm{Max}}$ and $\mathrm{COE}_{\mathrm{Min}}$ are the Nash-Sutcliffe coefficients calculated, respectively, for the maximum and minimum values of the parameter. 
The I.S is calculated for each parameter; the higher the value of the I.S, the more sensitive the model is to the parameter and, therefore, the greater its influence on the model results. I.S values near 0 indicate that any value adopted for the parameter within the analyzed range will not imply considerable changes in the model results.

\section{Model calibration and validation}

The objective of model calibration is to determine the parameters that result in simulated results closest to the observed hydrological variables, which include flow rate, runoff volume, and lag time. Thus, calibration is the optimization of the model parameters and error reduction (TUCCI, 2005). However, hydrological models are not always physically based, meaning they sometimes include parameters that cannot be measured in the field. The calibration of such parameter values is performed using existing hydrological information (TUCCI, 2005).

Calibration can be performed manually or automatically. Manual calibration, by trial and error, is an iterative process that continues until the user decides that the obtained results are satisfactory. Through this procedure, the experience and knowledge of the model user can be aggregated into the process. However, manual calibration can be a very slow, repetitive, and tiring process, especially when the model has a large number of parameters and the user is inexperienced (TUCCI; COLLISCHONN, 2003). An inexperienced modeler often finds it difficult to deduce the logic by which the parameters should be calibrated (TUCCI, 2005).

Automatic calibration is performed through optimization algorithms based on the intensive use of computers, which makes the calibration process faster and more efficient. However, the inappropriate use of this technique may impair hydrological model results. Therefore, it is important to acknowledge the limitations of automatic calibration methods (TUCCI; COLLISCHONN, 2003).

Once the model has been calibrated, it can then be validated. In validation, the model performance is assessed using different data than those used in the calibration. Thus, it is possible to verify whether the values of the parameters obtained in the calibration satisfactorily describe the hydrological behavior of the watershed.

\section{Flood Hazard Chart construction}

The construction of the Flood Hazard Chart is based on the maximum water level derived from the design storms simulated in the calibrated and validated hydrological-hydraulic model. The design storms can be obtained from local intensity-duration-frequency (IDF) equations, and then the design hyetograph can be established. The temporal distribution of precipitation is extremely important, as it can significantly influence the shape and peak value of the simulated hydrograph (BRANDÃO; RODRIGUES; COSTA, 2001); this can ultimately be reflected in the flood area and depths (MONTEIRO; KOBIYAMA, 2014).

To construct design hyetographs, the Huff method (HUFF, 1967), the alternating block method (CHOW; MAIDMENT; MAYS, 1988), the Chicago method (KEIFER; CHU, 1957 apud CHOW; MAIDMENT; MAYS, 1988), the triangular hydrograph method proposed by Yen and Chow (1980 apud CHOW; MAIDMENT; MAYS, 1988), and the method proposed by Pilgrim and Cordery (1975 apud CHOW; MAIDMENT; MAYS, 1988) may be used. The design hyetographs for each rain duration and return period are simulated in the selected hydrological-hydraulic model, and the simulated maximum flow rate or the simulated maximum water level are classified according to the risk warning levels defined for the stream or channel in question.

For each rain duration, the corresponding design storm is classified according to the risk level associated with the maximum water level (or maximum flow rate) obtained in the simulation. For a given rain duration and return period, the design storms whose respective maximum water level (or maximum flow rate) fall within the transition of two subsequent warning levels are identified and used as a range. In order to set the threshold between the two warning levels, several simulation attempts must be performed using different design storms from the identified range until the maximum water level converges to the upper limit of the warning. In other words, the maximum water level is computed from the simulations until it changes the warning level. When the warning level is changed, the previously simulated design storm is set as the threshold of the warning level.

Using the $10 \mathrm{~min}$ duration storm as an example, and assuming that the threshold between an orange and red warning is between 40.1 to $43.5 \mathrm{~mm}$, several design storms are simulated until the maximum water level exceeds the orange warning. The rainstorm immediately preceding this last one is set as the threshold between the orange and red warning levels. The Flood Hazard Chart construction is performed through the repetition of this procedure for all rain durations.

\section{Flood Hazard Chart assessment}

The Flood Hazard Chart is assessed using observed rain events and their maximum water levels (or maximum flow rates). The observed rain events are plotted in the hazard chart as a function of the total accumulated precipitation and its duration. The observed maximum water level of each rain event is compared to the chart warning level in order to verify whether the warning type agrees with the chart's warning.

\section{CASE STUDY: CACHOEIRINHA WATERSHED}

\section{Study area}

The proposed methodology was applied to the Cachoeirinha Stream Watershed (Belo Horizonte, MG, Brazil). The Cachoeirinha Watershed has a history of flooding and is highly urbanized. Its land use consists of commercial, residential, and industrial buildings and few green areas. The watershed has two hydrological monitoring stations that are part of the Hydrological Monitoring Program of the Belo Horizonte municipality (PBH).

The Cachoeirinha Stream is the primary stream of this watershed; together with the Pampulha Stream, it forms the Onça Stream, a tributary of the Velhas River, which in turn is a tributary of the São Francisco River. The Cachoeirinha Watershed covers 
an area of $15.79 \mathrm{~km}^{2}$ and receives an average annual rainfall of $1,450 \mathrm{~mm}$. The Cachoeirinha Stream is $7.12 \mathrm{~km}$ in length, of which $5.81 \mathrm{~km}$ runs through a closed channel and $1.21 \mathrm{~km}$ runs through an open channel. A tributary of this stream passes along the avenue Bernardo Vasconcelos, a main access route for the watershed neighborhoods that frequently endures flooding.

According to information provided by the Municipal Civil Defense of Belo Horizonte - COMDEC, the northeast region of Belo Horizontal (in which the Cachoeirinha Watershed is located) is the region with the largest number of flood episodes. From 1995 to 2016, the number of flooding episodes in the northeast region of Belo Horizonte amounted to $19 \%$ of the total number of floods registered in the municipality (BELO HORIZONTE, 2016).

Figure 2 depicts the location of the Cachoeirinha Stream within Belo Horizonte and a satellite image of its watershed from 2013. The watershed is highly impervious and has few green areas. The watershed streams and the hydrological monitoring stations, including two pluviometric stations (12 and 14) and one pluvio-fluviometric station (13), are also shown.

\section{Cachoeirinha Watershed data}

Cachoeirinha Watershed data were obtained from the drainage network register of Belo Horizonte city, known as SIG Drenagem. In this GIS database, plants, cross sections, channel singularities, and longitudinal profiles were obtained. Available topographic data were also used for the Cachoeirinha and Justiça Streams.
The rainfall and water level data were obtained from the Belo Horizonte Hydrological Monitoring System, which began operation in October 2011. Data recorded in the monitoring stations were measured every $10 \mathrm{~min}$. The selected rain events were those that generated warning levels according to the definition of Belo Horizonte municipality for the Cachoeirinha Stream fluviometric station (station 13). The events that produced (1) a yellow warning were those in which the water level was between $50 \%$ and $80 \%$ of the channel's height, i.e. $210 \leq$ water level $<336 \mathrm{~cm}$; (2) an orange warning were those in which the water level was between $80 \%$ and $100 \%$ of the channel's height, i.e. $336 \leq$ water level $<580 \mathrm{~cm}$ and; (3) a red warning were those in which the channel overflowed, i.e. water level $\geq 580 \mathrm{~cm}$. From October 2011 to December 2016, only the rain events which had no missing data in a 24-hour duration series were selected. Data from 2014 were not available. A total of 18 events were selected and are presented in Figure 3.

The return period (RT) of the selected rain events was estimated through the IDF equation proposed by Guimarães and Naghettini (1998) for the Belo Horizonte Metropolitan region (Equation 5).

$i=0.76542 . D^{-0.7059} \cdot P A^{0.5360} \cdot \mu_{T, d}$

where: $\mathrm{i}=$ rainfall intensity, associated with the return period in years $(\mathrm{mm} / \mathrm{h}) ; \mathrm{D}=$ rainfall duration (hours); $\mathrm{AR}=$ Average annual rainfall estimated for the watershed ( $\mathrm{mm} /$ year); and $\mu_{\mathrm{T}, \mathrm{d}}=$ regional dimensionless quantile associated with the return period and the rain duration (tabulated in GUIMARÃES; NAGHETTINI, 1998).

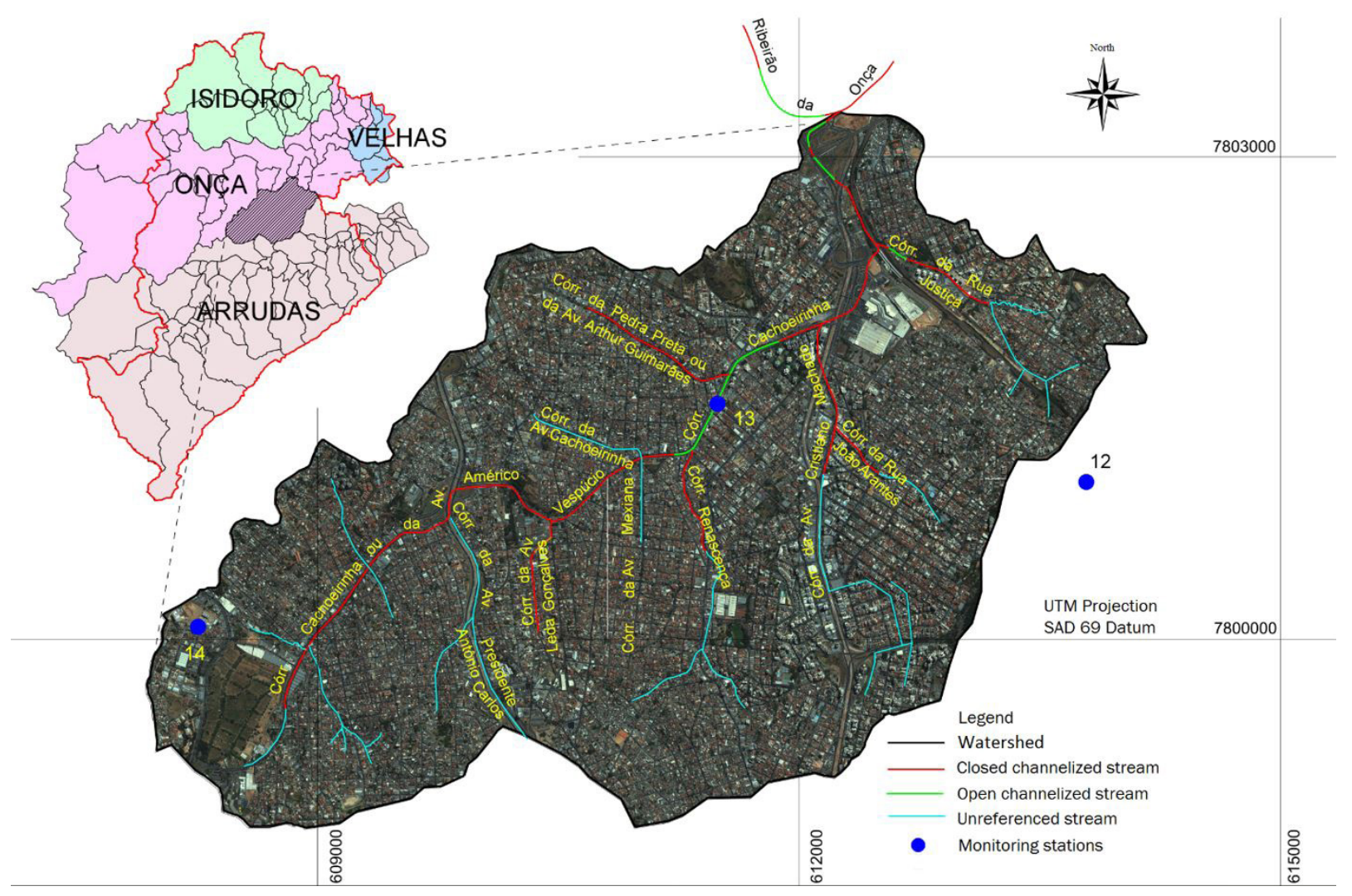

Figure 2. Cachoeirinha watershed location, main water courses and monitoring stations. 


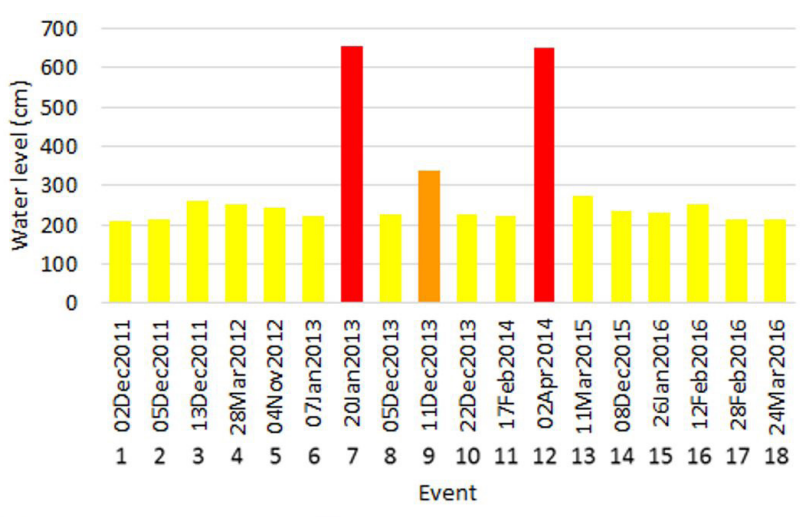

Yellow warning (50\% height) Orange warning (50\% height) $\square$ Red warning

Figure 3. Selected rain events for model's calibration and validation.

The RT and the warning level were considered in order to homogeneously split the rain events between calibration and validation steps. Flooded area data were not available for rain events which generated channel overflow. Thus, red warning rain events were selected for the validation, as the occurrence of channel overflow led to water spreading onto public roads and adjacent areas, preventing the exact definition of the water level.

Tables 1 and 2 summarize the characteristics of the selected events for the model calibration and validation, respectively.

The precipitation data from stations 12, 13, and 14 (Figure 2) were spatialized through the Thiessen Polygon method. The beginning and the end of the rain events were defined based on the observed water level. The beginning of the event was established when the water level began its increase, and the end of the event was determined when the water level returned to its initial value (before the increase).

The effective rainfall was obtained from the Soil Conservation Service's (SCS, currently the Natural Resources Conservation Service, NRCS) Curve Number method (NRCS, 2004). This method was chosen due to the availability of land use and soil classification data in Belo Horizonte city. Furthermore, the CN method is one of the most widely-used methods for simulating hydrological losses during event modeling in small watersheds (SINGH, 2013). Its widespread use is justified by its simplicity, stability, good predictability, and accurate estimates (PONCE; HAWKINS, 1996).

Silva et al. (1995) and Ramos (1998) classified the soils of Belo Horizonte into two hydrological groups, considering the NRCS Antecedent Moisture Condition II: the Complexo Belo Horizonte soils were classified as group B and the Supergrupo Minas soils as group D. Soils in the Cachoeirinha Watershed belong to group B. According to Tucci (2007), soil type B is sandy and has a higher permeability than the average of soils $C$ and $D$.

The $\mathrm{CN}$ values for soil groups $\mathrm{B}$ were obtained from Melo, Moura and Aguiar (2014), who proposed CN values based on the report of Teixeira (2013), who, in turn, conducted the land use classification for Belo Horizonte city based on two RapidEye satellite images from October 2009. The land use classes proposed for the Cachoeirinha Watershed in Teixeira (2013) included: urban, water, bare soil, dense vegetation, and low vegetation. Table 3 presents the values of $\mathrm{CN}$ adopted for each land use.
Table 1. Calibration rain events characteristics.

\begin{tabular}{cccccccc}
\hline $\mathbf{E}$ & $\mathbf{W L}$ & $\mathbf{P}_{\text {cum. }}$ & $\mathbf{D}$ & $\mathbf{I}$ & $\mathbf{P}_{\text {cum_peak }}$ & $\mathbf{T}_{\text {peak }}$ & $\mathbf{R T}$ \\
\hline 1 & 210 & 14.8 & 70 & 12.69 & 11.0 & 40 & 0.50 \\
2 & 216 & 30.0 & 90 & 19.97 & 19.2 & 40 & 0.77 \\
3 & 261 & 23.2 & 40 & 34.86 & 23.1 & 30 & 0.83 \\
4 & 254 & 38.2 & 130 & 17.64 & 21.4 & 30 & 0.93 \\
5 & 246 & 23.6 & 80 & 17.69 & 17.0 & 20 & 0.56 \\
6 & 223 & 50.0 & 150 & 20.00 & 35.9 & 50 & 2.69 \\
8 & 228 & 23.3 & 60 & 23.33 & 17.8 & 30 & 0.64 \\
9 & 337 & 47.4 & 140 & 20.31 & 34.2 & 40 & 2.03 \\
10 & 228 & 51.3 & 190 & 16.19 & 33.1 & 50 & 1.71 \\
\hline
\end{tabular}

$\mathrm{E}=$ Event; WL $=$ water level, $\mathrm{cm} ; \mathrm{P}_{\text {cum }}=$ Cumulated precipitation, $\mathrm{mm}$; $\mathrm{D}=$ Precipitation duration, minutes; I = Precipitation intensity, $\mathrm{mm} / \mathrm{h}$; $\mathrm{P}_{\text {cum_peak }}=$ Cumulated precipitation until maximum water level, $\mathrm{mm} ; \mathrm{T}_{\text {peak }}=$ Time to peak, minutes; RT = Return period, years.

Table 2. Validation rain events characteristics.

\begin{tabular}{cccccccc}
\hline $\mathbf{E}$ & $\mathbf{W L}$ & $\mathbf{P}_{\text {cum. }}$ & $\mathbf{D}$ & $\mathbf{I}$ & $\mathbf{P}_{\text {cum_peak }}$ & $\mathbf{T}_{\text {peak }}$ & $\mathbf{R T}$ \\
\hline 7 & 656 & 50.0 & 110 & 27.29 & 44.6 & 40 & 8.28 \\
11 & 222 & 23.3 & 70 & 19.97 & 16.7 & 30 & 0.58 \\
12 & 652 & 59.5 & 140 & 25.48 & 37.2 & 40 & 5.94 \\
13 & 273 & 23.3 & 60 & 23.34 & 20.8 & 30 & 0.70 \\
14 & 234 & 19.3 & 60 & 19.30 & 17.4 & 20 & 0.57 \\
15 & 231 & 29.6 & 100 & 17.78 & 24.8 & 60 & 0.67 \\
16 & 251 & 34.9 & 100 & 20.93 & 25.8 & 40 & 1.02 \\
17 & 214 & 41.7 & 70 & 35.77 & 39.2 & 50 & 2.65 \\
18 & 212 & 26.5 & 110 & 14.44 & 20.0 & 50 & 0.58 \\
\hline
\end{tabular}

$\mathrm{E}=$ Event; $\mathrm{WL}=$ water level, $\mathrm{cm} ; \mathrm{P}_{\text {cum. }}=$ Cumulated precipitation, $\mathrm{mm}$; $\mathrm{D}=$ Precipitation duration, minutes; $\mathrm{I}=$ Precipitation intensity, $\mathrm{mm} / \mathrm{h}$; $\mathrm{P}_{\text {cum_peak }}=$ Cumulated precipitation until maximum water level, $\mathrm{mm} ; \mathrm{T}_{\text {peak }}=$ Time to peak, minutes; $\mathrm{RT}=$ Return period, years.

Table 3. Adopted $\mathrm{CN}$ values for each land use.

\begin{tabular}{cc}
\hline Land use & Hydrologic soil group B \\
\hline Bare Soil & 82 \\
Urban area & 98 \\
Densely vegetated area & 66 \\
Low vegetated area & 79 \\
\hline
\end{tabular}

Source: Adapted from Teixeira (2013).

As a preliminary estimate, the percentage of impervious area in the watershed was assumed to correspond with the percentage of urban land use. However, there is a difference between the total impervious area (constructed and non-infiltrating surfaces, such as concrete, asphalt, and constructions) and the impervious area directly connected to the drainage system. According to Booth and Jackson (1997), the total impervious area presents two hydrological limitations: (1) it does not consider highly compacted pervious surfaces or those with low permeability in which surface runoff is similar to that produced by impervious surfaces; and (2) it does not consider that some paved surfaces may have no direct contribution to the drainage network system because they are not connected to gutters, manholes, and drainage channels. However, identifying directly connected surfaces to the drainage system is complex and laborious (BOOTH; JACKSON, 1997; LEE; HEANEY, 2003) and the calibration of the impervious 
area has been an alternative used in several studies (e.g. BARCO; WONG; STENSTROM, 2008).

Finally, the slope of the watershed was obtained through topographic data with contour lines at 5-m intervals, which was provided by Belo Horizonte municipality in a "dwg" file format.

\section{Hydrological and hydraulic modeling}

The SWMM 5.0 model was chosen for the development of this case study. SWMM is a widely-used model for catchment diagnostics, scenario simulations, and urban planning. It is a rainfall-runoff model that simulates surface runoff quantity and quality, especially in urban areas, and can be used both for the simulation of a single rainy event and for continuous long-term simulation. The model is able to simulate several hydrological processes: precipitation, interception, infiltration, evapotranspiration, depressions storage, and overland and drainage network flows. As such, it is one of the most used models in urban drainage studies (LENHS, 2012; NIAZI et al., 2017).

From the operational aspect, SWMM includes the catchments, conduits, and junctions as its basic units. These units respectively represent, the watershed divided into catchments, the drainage network, and other hydraulic elements such as pumps, orifices, storage units, and spillways. From the conceptual aspect, three methods are available to account for infiltration and compute effective rainfall: Horton, Green Ampt, and CN (NRCS) methods. In this work, as previously mentioned, the $\mathrm{CN}$ method was adopted.

For the transfer function, SWMM considers that the catchments behave as nonlinear reservoirs where the water level on the watershed surface and the outflow rate are represented by an equation analog to Manning's equation (Equation 6).

$Q_{S}=w \cdot \frac{1}{n}\left(d_{t}-d_{p}\right)^{5 / 3} \cdot S_{0}{ }^{1 / 2}$

where: $\mathrm{Q}_{\mathrm{S}}=$ catchment outflow rate; $\mathrm{w}=$ characteristic width of overland flow; $\mathrm{n}=$ Manning's $\mathrm{n}$ for overland flow; $\mathrm{d}_{\mathrm{t}}=$ catchment water level; $\mathrm{d}_{\mathrm{p}}=$ initial hydrological losses; and $\mathrm{S}_{0}=$ catchment mean slope.

The flow routing in the drainage network is performed using 1D Saint-Venant equations, and the level of complexity (kinematic or dynamic wave) can be chosen by the user according to the simulation objectives. In the present work, the dynamic wave model was used due to the need to represent pressurized flow, backwater, and overflow effects. Flow routing can also be simulated based on steady flow (SILVA et al., 2015).

The parameter width of catchment $(\mathrm{w})$ provides an estimate of the overland flow path by referring to the concentration time of the catchment. Thus, for a given catchment surface, the greater its width, the smaller the distance the flow must travel to reach the channel. In urban areas, the estimation of this parameter based on morphological characteristics of the catchment (length, width, area) is very inexact, mainly due to the existence of drainage networks impacting the concentration time.

In SWMM, the Cachoeirinha Watershed was subdivided into 39 catchments according to drainage network and the Belo Horizonte Drainage Master Plan - PDDBH (BELO HORIZONTE, 2000). The area and width of the catchments were calculated, as well as their mean values of slope, $\mathrm{CN}$, and percentage of impervious area. The mean $\mathrm{CN}$ was obtained for each catchment according to the weighted average of the $\mathrm{CN}$ values corresponding to each land use. The weighting factor was the surface occupied by each land use.

In SWMM, the surface runoff from impervious areas not directly connected to the drainage system may be routed to pervious areas. However, the estimation of these areas in this case study would be difficult to perform because the resolution of the remote sensing images used to assess land use does not allow us to identify the connection elements of the impervious areas, such as gutters and manholes, to the drainage system. Additionally, the spatial scale analyzed (watershed surface is around $16 \mathrm{~km}^{2}$ ) makes it difficult to obtain through field investigations, as performed for example by Lee and Heaney (2003). Thus, it was decided to calibrate the percentage of impervious area in the watershed, as presented later in this text.

The representation of the hydrographic network was performed using 379 conduits (channel reaches) and 379 nodes. For each conduit, its length, type, and cross section dimensions and roughness coefficient were inserted. The nodes were used to define the beginning and end of the conduits, manholes, and tributaries' confluences with the main stream, and to represent singularities such as steps. For each node, elevation values and maximum conduit depth were set. In the node representing monitoring station 13, a flow rate was inserted referring to the baseflow $\left(\mathrm{Q}=0,158 \mathrm{~m}^{3} / \mathrm{s}\right)$. This flow rate was obtained from Belo Horizonte (2010).

For manhole nodes, the value of $2.0 \mathrm{~m}$ for surcharge depth was also inserted. This depth represents the height of the water that can accumulate in the neck of the manhole in case of conduit surcharge. This value corresponds to the average height of the existing manhole necks in the watershed.

Figure 4 illustrates the Cachoeirinha Watershed in the SWMM model, with the representation of the catchments, conduits, and nodes.

\section{Sensitivity analysis}

The calibration rain events were used to simulate one-at-a-time parameter variation for the sensitivity analysis. The following parameters were analyzed: $n$-pervious (n-perv) and $n$-impervious (n-imper) (roughness coefficients for overland flow over the pervious and impervious portion of the catchment, respectively), D-Pervious (D-perv) and D-impervious (D-imper) (depth of depression storage on the pervious and impervious portion of the catchment, respectively), and $\mathrm{n}$ (conduit roughness coefficient).

Table 4 indicates the parameter ranges used in this study, as recommended by the SWMM User Manual (LENHS, 2012).

For each parameter, simulations were performed using the calibration events by first applying the minimum parameter value, then using its maximum value (Table 4). The simulation results were assessed using the COE (Equation 1). The maximum and minimum $\mathrm{COE}$ for each parameter were considered equal to the mean of the minimum or maximum COE calculated for the simulated events. The sensitivity of the model to each parameter was computed through the I.S (Equation 2). 


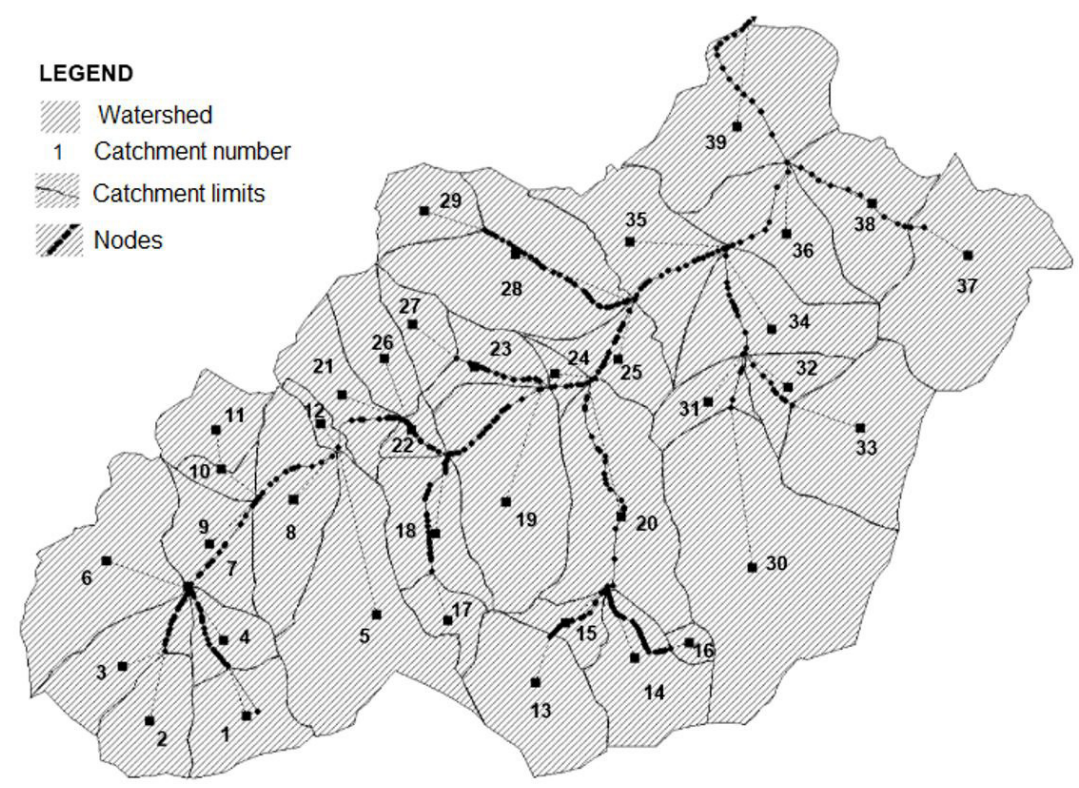

Figure 4. Cachoeirinha Watershed representation in SWMM.

Table 4. Parameters' range values.

\begin{tabular}{ccccc}
\hline \multirow{2}{*}{ Element } & Parameter & \multirow{2}{*}{ Unit } & \multicolumn{2}{c}{ Range interval } \\
\cline { 4 - 5 } Catchment & n-perv & - & 0.13 & Max \\
& n-imper & - & 0.011 & 0.40 \\
& D-perv & $\mathrm{mm}$ & 2.54 & 0.024 \\
Channel & D-imper & $\mathrm{mm}$ & 1.27 & 7.62 \\
& $\mathrm{n}$ & - & 0.012 & 2.54 \\
\hline
\end{tabular}

Min = minimum; Max = maximum; n-perv = roughness coefficients for overland flow over the pervious area; $\mathrm{n}$-imper $=$ roughness coefficients for overland flow over the impervious area; D-perv $=$ depression storage on the pervious area; $\mathrm{D}$-imper $=$ depression storage on the impervious area); $\mathrm{n}=$ conduit roughness coefficient. Source: Lenhs (2012).

\section{Model calibration}

First, a pre-calibration of the parameters width of the catchments (w) and percentage of impervious area was performed. The pre-calibration of these parameters was motivated by the fact that no reference values were found in the literature, since they represent intrinsic characteristics of a given catchment.

Rain event $1(02 / 12 / 2011)$ was used to define the width of the catchments. This rain event was the best fit for the model in the sensitivity analysis. Due to the difficulties in estimating the value of parameter $\mathrm{w}$, as previously explained, the first estimate was the square root of the catchment area. The $\mathrm{w}$ values were increased $(+\Delta \mathrm{w})$ and then reduced $(-\Delta \mathrm{w})$ as follows: w- $50 \%$; $\mathrm{w}-75 \%$; w-80\%; w- $99 \%$; $+50 \%$; $+75 \%$; w $+85 \%$; w $+100 \%$. The model performance was assessed using relative COE values (Equation 7) and the relative error (Equation 3) between the maximum observed and simulated water level.

$$
\triangle \mathrm{COE}=\mathrm{COE}_{\boldsymbol{x} \pm \Delta x}-\mathrm{COE}_{\text {original }} / \mathrm{COE}_{\text {original }} \times 100
$$

where: $\Delta \mathrm{COE}=$ percentage variation of $\mathrm{COE} ; \mathrm{COE}_{\text {original }}=\mathrm{COE}$ obtained in the simulation with the initial parameter value; $\mathrm{COE}_{\mathrm{x} \pm \Delta \mathrm{x}}=\mathrm{COE}$ obtained in the simulation with the variation of the parameter value $\mathrm{x}$, by $\Delta \mathrm{x}$.
The pre-calibration of the percentage of impervious area was performed by reducing its initial value by $10 \%, 15 \%, 20 \%$, $25 \%, 30 \%, 35 \%, 40 \%$, and $45 \%$. The RMSE (Equation 2) was used to assess model performance in simulating the maximum water level, since its value defines the warning level in the monitoring station. This assessment was performed for all calibration rain events. For each percentage of impervious area reduction, the mean RMSE was determined considering the RMSE values from each rain event. The percentage of impervious area which resulted in the lowest mean RMSE was then selected.

After pre-calibration, the calibration of the parameters to which the model was more sensitive, as indicated by the sensitivity analysis, was performed. The manual trial and error method was used to approximate the value of the simulated water level in comparison to the observed water level in the fluviometric station 13. Several simulations were carried out, using different values for each parameter. The parameter values which resulted in the best event-individual fits were combined. New simulations were then carried out considering the simultaneous variation of these parameters.

The model performance was assessed using the COE (Equation 1) and the RMSE (Equation 2) through a comparison of the observed and simulated water levels. The RMSE was 
calculated considering only the maximum water level. Thus, the combination of parameters that resulted in the highest value of COE and lowest RMSE was adopted for the Cachoeirinha Watershed modeling. To classify the model performance in the present study, the criteria used by Collischonn (2001) were applied: acceptable performance for $\mathrm{COE}>0.36$ and good performance for $\mathrm{COE}>0.75$.

\section{Model validation}

For the model validation, nine rain events (Table 2) were simulated considering the calibrated parameters' values. The model performance in the validation step was assessed using the COE (Equation 1).

\section{Flood Hazard Chart construction}

The design storms for the return periods of 2, 5, 10, 25, 50 , and 100 years and durations between 5 and 480 minutes were computed (Equation 5). The average annual rainfall was 1,450 mm.

The design storms hyetographs were obtained using the temporal distribution graphs developed by Guimarães and Naghettini (1998) for Belo Horizonte Metropolitan Region based on the Huff method (HUFF, 1967). For each design storm duration, the temporal distribution associated with the exceedance probability of $50 \%$ was used.

The design storms were simulated in the calibrated and validated Cachoeirinha hydrological-hydraulic model to obtain the maximum water levels corresponding to each one. The maximum water level values obtained were classified according to warning levels (yellow, orange, and red) of the Cachoeirinha Stream at station 13. Finally, several simulations were performed using the design storm values within the warning levels transition range until the convergence of the maximum water level to the upper limit of the warning level.

\section{Flood Hazard Chart assessment}

The Flood Hazard Chart constructed for the Cachoeirinha Watershed was assessed using the same observed rain events used in the calibration and validation steps. The rain events were plotted in the Flood Hazard Chart as a function of total accumulated precipitation and duration. The maximum water level observed for these pairs (precipitation and duration) were compared to the corresponding Flood Hazard Chart warning level.

\section{RESULTS AND DISCUSSION}

\section{Sensitivity analysis}

The model presented greater sensitivity to the following parameters (Table 5): n-imper, D-imper, and n. These parameters were also reported in the literature as the most sensitive. For example, Niazi et al. (2017) evaluated 92 studies that used SWMM in urban and peri-urban areas and found that D-imper, n-imper, and n-perv were reported among the most sensitive parameters. Jiang, Chen and Wang (2015) reported similar results. Furthermore, when applying SWMM to a watershed with $217 \mathrm{~km}^{2}$, Barco, Wong and Stenstrom (2008) reported that the variation of $n$ caused greater impacts on the peak time.

The influence of the impervious area parameters on the simulated water level values was already expected, since according to the study developed by Teixeira (2013), 87\% of the watershed area is urbanized.

\section{Model calibration}

The results presented here refer to the two calibration steps performed: the pre-calibration of the parameters $\mathrm{w}$ and percentage of impervious area, whose direct association to the physical characteristics of urban catchments is uncertain, and the calibration of the most sensitive parameters, as indicated by the sensitivity analysis.

\section{Catchment width (w)}

Table 6 presents the results of the pre-calibration of the parameter $\mathrm{w}$ considering the maximum water level in rain event 1, which had two water level peaks (Figure 5). According to the variations obtained in the COE values, the best fits were obtained for $\mathrm{w}=\mathrm{w}+100 \%, \mathrm{w}=\mathrm{w}+75 \%$, and $\mathrm{w}=\mathrm{w}+50 \%$. Figure 5 presents the results for these simulations. The simulation with $\mathrm{w}=\mathrm{w}+50 \%$ was adopted because it presented the lowest relative error between the two peaks.

Table 5. Sensitivity analysis.

\begin{tabular}{ccc}
\hline Element & Parameters & I.S. \\
\hline Catchment & n-perv & 0.03 \\
& n-imper & 0.57 \\
& D-perv & 0.01 \\
& D-imper & 0.67 \\
Conduit & n (Manning) & 0.22 \\
\hline
\end{tabular}

I.S. = Sensitivity Index; $\mathrm{n}$-perv = roughness coefficients for overland flow over the pervious area; $\mathrm{n}$-imper $=$ roughness coefficients for overland flow over the impervious area; $\mathrm{D}$-perv $=$ depression storage on the pervious area; $\mathrm{D}$-imper $=$ depression storage on the impervious area); $\mathrm{n}=$ conduit roughness coefficient.

Table 6. Pre-calibration of catchment width.

\begin{tabular}{|c|c|c|c|c|c|}
\hline \multirow[t]{2}{*}{ W variation } & \multicolumn{2}{|c|}{$\begin{array}{c}\text { Maximum } \\
\text { simulated } \\
\text { WL } 1\end{array}$} & \multicolumn{2}{|c|}{$\begin{array}{c}\text { Maximum } \\
\text { simulated WL } 2\end{array}$} & \multirow[t]{2}{*}{$\begin{array}{c}\Delta \mathrm{COE} \\
(\%)\end{array}$} \\
\hline & WL & Error \% & WL & Error $\%$ & \\
\hline $\mathrm{w}=\mathrm{w}+50 \%$ & 2.03 & 3.30 & 1.77 & 11.79 & +530 \\
\hline $\mathrm{w}=\mathrm{w}+75 \%$ & 1.83 & 12.74 & 1.82 & 14.15 & +830 \\
\hline $\mathrm{w}=\mathrm{w}+85 \%$ & 2.20 & 4.72 & 1.89 & 17.45 & +300 \\
\hline $\mathrm{w}=\mathrm{w}+100 \%$ & 2.13 & 1.42 & 1.82 & 14.15 & +630 \\
\hline $\mathrm{w}=\mathrm{w}-50 \%$ & 1.51 & 27.83 & 1.72 & 9.43 & -70 \\
\hline $\mathrm{w}=\mathrm{w}-75 \%$ & 1.27 & 39.15 & 1.45 & 3.30 & -330 \\
\hline $\mathrm{w}=\mathrm{w}-80 \%$ & 1.22 & 41.51 & 1.40 & 5.66 & -370 \\
\hline $\mathrm{w}=\mathrm{w}-99 \%$ & 3.01 & 42.92 & 3.42 & 89.62 & -243 \\
\hline
\end{tabular}




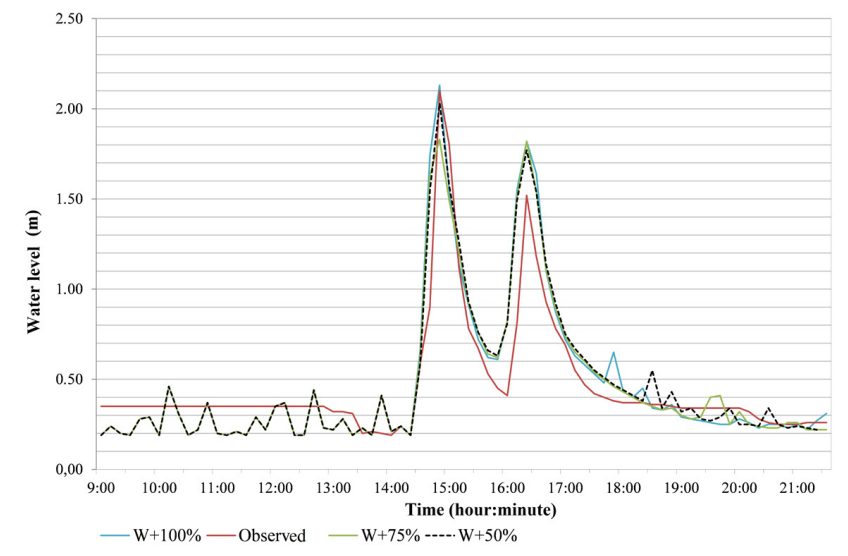

Figure 5. Pre-calibration of catchment width: observed and simulated hydrographs for different catchments widths $(\mathrm{w}+100 \%$; $\mathrm{w}+75 \%$ e w $+50 \%$ ) for Event 1 .

\section{Percentage of impervious area}

Table 7 presents the maximum simulated and observed water levels for each variation of the percentage of impervious area, as well as the calculated RMSE values. The results indicate that the smallest error was obtained for a reduction of $40 \%$ in the percentage of pervious area, which was then adopted in the model.

Based on the study by Teixeira (2013), the percentage of impervious area in the Cachoeirinha Watershed was $87 \%$. After reducing the percentage of the impervious area by $40 \%$, as indicated by the pre-calibration, this parameter assumed the value of $53 \%$. This is an acceptable reduction when compared to the literature results. Lee and Heaney (2003) carried out a detailed analysis of the impervious area in an urban microcatchment (5.81 ha) using GIS data and field investigations. The authors found that only $36 \%$ of the impervious area was connected to the drainage system.

\section{Parameters: n-imper, D-imper and N (Manning's roughness coefficient)}

Event 1 was simulated using the one-at-a-time variation of $\mathrm{n}$-imper, D-imper, and channels $\mathrm{n}$, while keeping the remaining parameters unchanged. Table 8 reveals the values of the unchanged parameters, as well as the calibrated parameters that presented the best fits (using COE) in the performed simulations.

\section{Model performance}

\section{Model calibration}

From the identification of the ranges for the most sensitive parameters using rain event 1, 36 combinations of parameter values were obtained to calibrate the model using nine calibration rain events; four $\mathrm{n}$-imper values $(0.012 ; 0.013 ; 0.014$ and 0.015$)$, three values of $\mathrm{n}(0.015 ; 0.016$ and 0.017$)$, and three values of D-imper $(1.37 ; 1.87$ and 1.97$)$ were tested.
Table 7. Pre-calibration of catchment percentage of impervious area, observed and simulated maximum water levels, by event.

\begin{tabular}{cccccccccc}
\hline & \multicolumn{8}{c}{ Maximum water levels (m) } \\
\cline { 2 - 9 } $\mathbf{E}$ & \multicolumn{8}{c}{ Reduction in percentage } & Obs. \\
\cline { 2 - 9 } & $\mathbf{0}$ & $\mathbf{1 0}$ & $\mathbf{2 0}$ & $\mathbf{2 5}$ & $\mathbf{3 0}$ & $\mathbf{3 5}$ & $\mathbf{4 0}$ & $\mathbf{4 5}$ & \\
\hline $\mathbf{1}$ & 1.84 & 1.64 & 1.71 & 1.58 & 1.62 & 1.54 & 1.50 & 1.42 & 2.10 \\
$\mathbf{2}$ & 3.09 & 2.77 & 2.58 & 2.98 & 2.52 & 2.20 & 2.39 & 2.97 & 2.16 \\
$\mathbf{3}$ & 3.72 & 3.55 & 3.95 & 3.38 & 3.21 & 3.15 & 2.64 & 2.74 & 2.61 \\
$\mathbf{4}$ & 3.40 & 3.25 & 3.00 & 2.88 & 2.77 & 2.73 & 2.80 & 2.86 & 2.54 \\
$\mathbf{5}$ & 3.00 & 2.80 & 2.69 & 2.53 & 2.73 & 2.70 & 2.43 & 2.26 & 2.46 \\
$\mathbf{6}$ & 4.14 & 3.86 & 3.47 & 3.58 & 3.16 & 3.20 & 2.98 & 2.85 & 2.23 \\
$\mathbf{8}$ & 3.07 & 3.00 & 2.61 & 2.53 & 2.36 & 2.28 & 2.45 & 2.12 & 2.28 \\
$\mathbf{9}$ & 4.23 & 3.81 & 3.54 & 3.40 & 3.23 & 3.10 & 2.97 & 2.80 & 3.37 \\
$\mathbf{1 0}$ & 3.36 & 3.30 & 3.21 & 3.03 & 2.98 & 2.77 & 2.67 & 2.63 & 2.28 \\
$\mathbf{R M S E}$ & $\mathbf{1 . 0 2}$ & $\mathbf{0 . 8 5}$ & $\mathbf{0 . 7 4}$ & $\mathbf{0 . 6 8}$ & $\mathbf{0 . 5 0}$ & $\mathbf{0 . 4 7}$ & $\mathbf{0 . 3 9}$ & $\mathbf{0 . 4 9}$ & - \\
\hline
\end{tabular}

$\mathrm{E}=$ event; RMSE $=$ Root Mean Square Error, meter; Obs. = Observed.

Table 8. Pre calibration of n-imper, D-imper and n (Event 1).

\begin{tabular}{|c|c|c|c|c|}
\hline $\begin{array}{l}\text { Calibrated } \\
\text { Parameter }\end{array}$ & n-imper. & D-imper. & \multicolumn{2}{|c|}{ n (Manning) } \\
\hline Variation range & 0.011 a 0.024 & 1.27 a 2.54 & \multicolumn{2}{|c|}{0.012 a 0.017} \\
\hline \multirow[t]{6}{*}{ Fixed Parameter } & $\mathrm{w}=\mathrm{w}+50 \%$ & \multirow{2}{*}{$\begin{array}{l}\mathrm{w}=\mathrm{w}+50 \% \\
\mathrm{n} \text {-perv. }=0.25\end{array}$} & \multicolumn{2}{|c|}{$\mathrm{w}=\mathrm{w}+50 \%$} \\
\hline & $\mathrm{n}$-perv. $=0.25$ & & n-pe & $=0.25$ \\
\hline & D-perv. $=3.80$ & \multirow{2}{*}{ D-perv. $=3.80$} & \multirow{3}{*}{\multicolumn{2}{|c|}{$\begin{array}{l}\text { D-perv. }=3.80 \\
\text { D-imper. }=1.9 \\
\text { n-imper }=0.01\end{array}$}} \\
\hline & s-imper. $=1.90$ & & & \\
\hline & - & \multirow{2}{*}{$\begin{array}{c}\mathrm{n} \text {-imper. }=0.017 \\
\mathrm{n}=0.018\end{array}$} & & \\
\hline & $\mathrm{n}=0.018$ & & & \\
\hline \multirow[t]{5}{*}{ Best results } & Value $\Delta \mathrm{COE}$ & Value $\Delta \mathrm{COE}$ & Value & $\Delta \mathrm{COE}$ \\
\hline & 0.012 & 1.37 & 0.015 & 69 \\
\hline & 0.013 & 1.87 & 0.016 & 46 \\
\hline & 0.014 & 1.97 & 0.017 & 46 \\
\hline & 0.015 & - & - & - \\
\hline
\end{tabular}

$\mathrm{w}=$ catchment width; $\mathrm{n}$-perv $=$ roughness coefficients for overland flow over the pervious area; $n$-imper $=$ roughness coefficients for overland flow over the impervious area; D-perv $=$ depression storage on the pervious area; $\mathrm{D}$-imper $=$ depression storage on the impervious area) $\mathrm{n}=$ conduit roughness coefficient.

The best parameter values, considering the mean COE and RMSE of the nine events, were $n$-imper $=0.015, \mathrm{n}=0.015$, and D-imper $=1.87$, with a mean COE and RMSE of 0.72and 0.38 , respectively. Table 9 indicates the calibrated parameters values. Figures 6 and 7 present the simulation results for the best (rain event 2) and worst (rain event 6) model performances using the calibrated parameter values.

Figure 8 reveals the calculated COEs, as well as the average COE, for all calibration rain events. The mean COE calculated for the Cachoeirinha model was 0.72 ; therefore, it may be considered acceptable (COLLISCHONN, 2001).

Event 6 presented the lowest $\mathrm{COE}$ between the rain events. The relative error was $26 \%$, which is considered unacceptable according to some literature references that limit model errors to $15 \%$. For example, Beck et al. (2017) proposes that a model with a relative error of $18 \%$ is acceptable, while Pfannerstill, 
Table 9. Adopted parameter values.

\begin{tabular}{cc}
\hline Parameters & Adopted values \\
\hline $\mathrm{w}$ & $\mathrm{w}=\mathrm{w}_{0}+50 \%$ \\
n-perv & 0.25 \\
n-imper & 0.015 \\
D-perv & 2.54 \\
D-imper & 1.87 \\
n (Manning) & 0.015 \\
\hline
\end{tabular}

$\mathrm{w}=$ catchment width; $\mathrm{n}$-perv $=$ roughness coefficients for overland flow over the pervious area; $\mathrm{n}$-imper $=$ roughness coefficients for overland flow over the impervious area; D-perv = depression storage on the pervious area; $\mathrm{D}$-imper $=$ depression storage on the impervious area); $\mathrm{n}=$ conduit roughness coefficient.

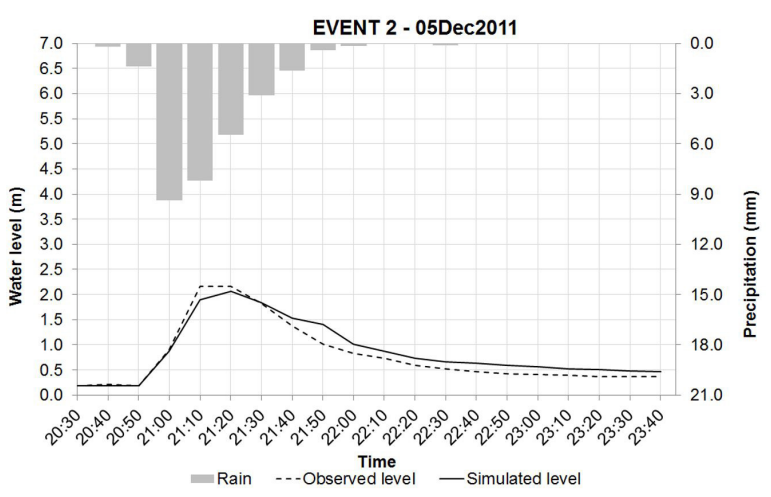

Figure 6. Simulation of event $2-\mathrm{COE}=0.93$.

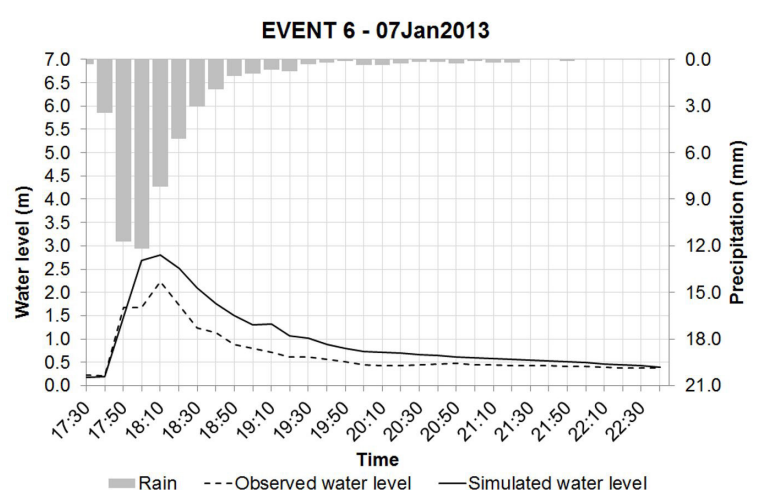

Figure 7. Simulation of event $6-\mathrm{COE}=0.32$.

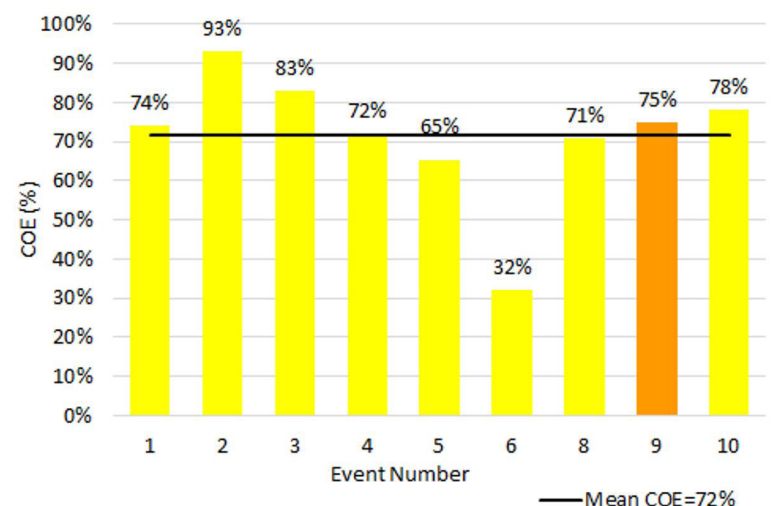

Figure 8. COE - Calibration rain events; all events presented a yellow warning except for event 9 , which presented an orange warning.
Guse and Fohrer (2014) consider errors up to 30\% acceptable. In Figure 7, an observed and simulated hydrogram of rain event 6 is presented. Between 17:40 and 18:00, the observed water level remained constant. Researchers assumed that this behavior was caused by an error in the water level register. This compromised the model performance assessment for this event, since in the ascending portion of the hydrograph, the tendency of the water level is to increase and not stabilize.

\section{Model validation}

The validation rain events were simulated using the calibrated parameter values to assess the model accuracy in predicting the observed water levels. Figures 9 and 10 reveal the events that obtained the best and worst COE performance in the simulation. Figure 11 presents the COE values for all validation events, as well as the COE's average.

In general, the model was able to represent the water level observed in most of the rain events. The COE's average for the validation events was 0.70 , indicating that the model performance is acceptable. Thus, it can be said that the calibrated model reproduces the hydrological response of the Cachoeirinha Watershed with high accuracy.

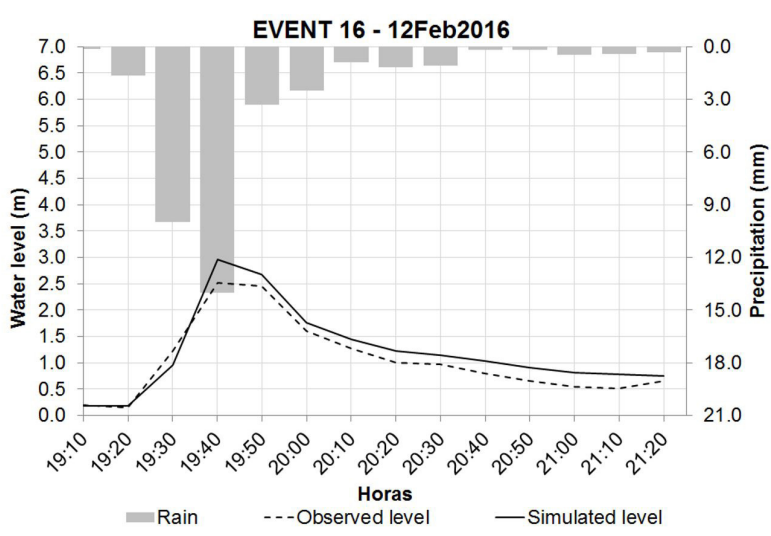

Figure 9. Simulation of event $16-\mathrm{COE}=0.89$.

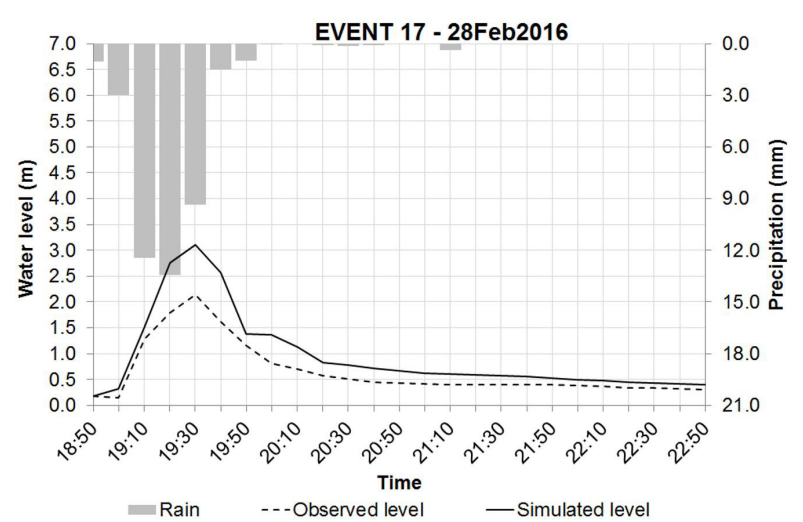

Figure 10. Simulation of event $17-\mathrm{COE}=0.42$. 
Figure 11 reveals that events 7,12, and 17 obtained the lowest $\operatorname{COE}(0.49,0.50$, and 0.42 , respectively). These rain events had the highest rain intensities and RT (Table 2). In rain events 7 and 12, channel overflow occurred; in rain event 17, a yellow warning was

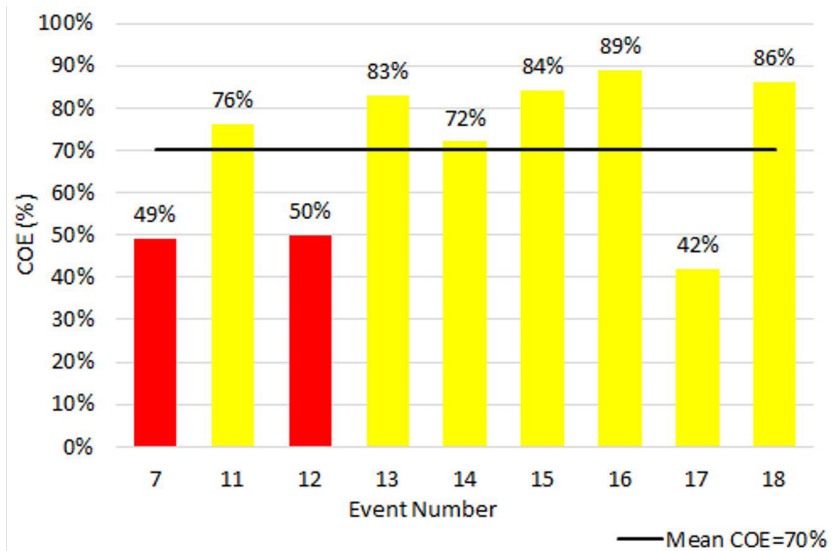

Figure 11. COE - Validation rain events, all events had yellow warning, except events 7 and 12, that presented red warning. launched. The model underestimated the maximum water level of the two events that generated red warnings; the maximum observed water levels were $6.56 \mathrm{~m}$ and $6.52 \mathrm{~m}$, and the simulated ones were $3.61 \mathrm{~m}$ and $3.18 \mathrm{~m}$, respectively, in events 7 and 12 .

The model was not able to reproduce the channel overflow for events 7 and 12. This is likely due to the SWMM's limitations, which include the inability to represent channel singularities such as beams, transitions, steps, and pillars. A tentative attempt to represent such singularities by introducing adaptations in the model was made, but it resulted in numerical errors. In addition to the impossibility of representing certain structural characteristics of the channel, SWMM cannot consider the occurrence of debris or the possibility of siltation. Such conditions reduce the channel capacity and may result in overflow.

The existing beams in the open channel reaches increase the possibility of overflows in the Cachoeirinha Stream, as stated in the study "Consolidation of the Flood Diagnosis in the Cachoeirinha Stream and the Pampulha and Onça Rivers" (BELO HORIZONTE, 2011). This study also reported the occurrence of flow regime changes in some stream reaches. The hydraulic modeling of supercritical or transcritical flow in channels is complex and subject to inaccuracies due to simplifications in the

Table 10. Maximum water levels according to warning levels.

\begin{tabular}{|c|c|c|c|c|c|c|}
\hline \multicolumn{7}{|c|}{ Maximum water level (cm) } \\
\hline \multirow{2}{*}{$\frac{\text { Duration }}{\text { (min) }}$} & \multicolumn{6}{|c|}{ RT (years) } \\
\hline & 2 & 5 & 10 & 25 & 50 & 100 \\
\hline 5 & 378 & 408 & 456 & 502 & 516 & 543 \\
\hline 10 & 484 & 434 & 544 & 475 & 584 & 598 \\
\hline 15 & 424 & 545 & 530 & 559 & 599 & 588 \\
\hline 30 & 455 & 533 & 514 & 555 & 570 & 595 \\
\hline 45 & 370 & 446 & 484 & 577 & 654 & 580 \\
\hline 60 & 360 & 382 & 466 & 507 & 577 & 590 \\
\hline 90 & 324 & 351 & 378 & 510 & 554 & 572 \\
\hline 120 & 271 & 338 & 355 & 419 & 502 & 489 \\
\hline 180 & 233 & 299 & 318 & 346 & 366 & 490 \\
\hline 240 & 224 & 270 & 320 & 357 & 365 & 356 \\
\hline 480 & 190 & 200 & 243 & 261 & 281 & 318 \\
\hline
\end{tabular}

Hazard warning level: white $=$ channel normal condition; yellow and orange $=50 \%$ and $80 \%$ of the channel height, respectively; red $=$ channel overflow; $\mathrm{RT}=$ Return period, years.

Table 11. Design storms classification according to warning levels.

\begin{tabular}{|c|c|c|c|c|c|c|}
\hline \multicolumn{7}{|c|}{ Design storm (mm) } \\
\hline \multirow{2}{*}{$\begin{array}{c}\text { Duration } \\
\text { (min) }\end{array}$} & \multicolumn{6}{|c|}{ RT (years) } \\
\hline & 2 & 5 & 10 & 25 & 50 & 100 \\
\hline 5 & 18.5 & 22.8 & 26.1 & 29.6 & 32.7 & 35.5 \\
\hline 10 & 22.67 & 27.3 & 31.9 & 36.3 & 40.1 & 43.5 \\
\hline 15 & 25.5 & 30.7 & 35.8 & 40.7 & 44.9 & 48.7 \\
\hline 30 & 31.3 & 37.3 & 43.4 & 49.2 & 54.1 & 58.6 \\
\hline 45 & 35.3 & 42.5 & 49.8 & 56.6 & 62.5 & 67.8 \\
\hline 60 & 38.4 & 46.5 & 54.7 & 62.4 & 69.1 & 75.1 \\
\hline 90 & 43.3 & 52.4 & 61.5 & 70.2 & 77.6 & 84.4 \\
\hline 120 & 47.1 & 56.9 & 66.8 & 76.2 & 84.2 & 91.5 \\
\hline 180 & 53.1 & 64.3 & 75.6 & 86.3 & 95.4 & 103.8 \\
\hline 240 & 57.69 & 69.6 & 81.6 & 92.7 & 102.4 & 111.2 \\
\hline 480 & 70.80 & 86.0 & 101.3 & 115.7 & 128.1 & 139.4 \\
\hline
\end{tabular}

Hazard warning level: white $=$ channel normal condition; yellow and orange $=50 \%$ and $80 \%$ of the channel height, respectively; red $=$ channel overflow; RT $=$ Return period, years. 
model equations and inadequacies in the boundary conditions (DJORDJEVIĆ; PRODANOVIĆ; WALTERS, 2004).

The hypotheses presented here may justify the model failure in simulating intense rain events. Thus, future studies should perform a more detailed analysis of the above-mentioned limitations in order to improve the modeling. In the present study, although the COEs were lower for these events, the modeling was still considered acceptable according to the reference values (COE between 0.35 and 0.75 ). Furthermore, it is noteworthy that even if the model was not able to accurately represent the amplitude of the observed hydrographs, it represented the hydrograph characteristic times very well, including ascension, recession, and peak times; these times are of great relevance for flood forecasting and early warning systems.

\section{Design storms}

Table 10 indicates the maximum water levels obtained from the simulations of the design storms, classified by warning level colors, as defined for the Cachoeirinha Watershed fluviometric station 13 (yellow: $50 \%$ of the channel's height; orange: $80 \%$ of the channel's height; and red: channel overflow condition).

Table 11 presents the precipitation data for various durations and RT, and the warning level according to water level.

\section{Flood Hazard Chart}

From the simulation results of the design storms in Cachoeirinha watershed hydrological-hydraulic model, the Flood Hazard Chart was constructed according to the methodology above described. Figure 12 presents the proposed chart.

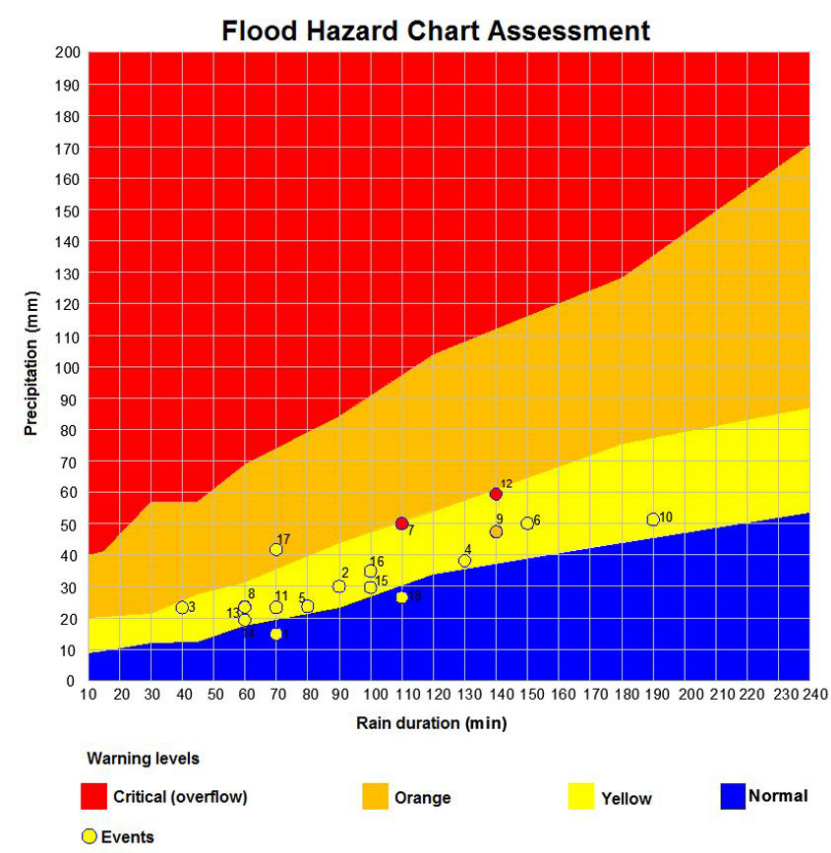

Figure 12. Assessment of the proposed Flood Hazard Chart for Cachoeirinha Watershed.

\section{Flood Hazard Chart assessment}

The observed events were plotted in the constructed chart in order to evaluate the proposed Flood Hazard Chart (Figure 12). Among the 18 rain events, 12 were classified as yellow warning levels; this is in agreement with the warning levels found on the proposed chart. The rain events include numbers $2,3,4,5,6,8$, $10,11,13,14,15$, and 16 . Although rain events 1 and 18 did not coincide with the proposed warning level, they revealed a good approximation.

However, the model was not able to accurately represent the rain events that generated orange and red warning levels. Rain events 7, 9, and 12 were simulated by the model and did not generate the observed warning levels. In addition to the limitations in representing the structural singularities of the channel (previously discussed), the red and orange warnings were very few. In the calibration, all events except one were yellow, which hinders the ability to achieve a model calibration that represents extreme situations.

In order to identify what could have influenced the incorrect representation of critical events, correlation analyses between the observed water levels and (1) precipitation intensity and (2) the number of antecedent dry days were performed despite the limited number of data (18 events). Such analyses were inconclusive; it was not possible to establish any relationship between the watershed hydrological response and the analyzed variables.

It is well known that the temporal and spatial distribution of precipitation can considerably influence the shape and peak of a hydrograph (MONTEIRO; KOBIYAMA, 2014). According to Brandão, Rodrigues and Costa (2001), a high-intensity precipitation concentrated at the end of a rain event will generate a runoff greater than another whose maximum intensity occurs at the beginning of the rain event. Specifically, if the rainfall intensity peak occurs at the end of the event, the effective precipitation will be similar to the total precipitation, since the initial losses have already occurred. On the contrary, if the precipitation peak occurs at the beginning of the rain event, only a part of this will generate runoff, and thus will contribute to superficial flow, which will be lower than that of the first situation.

One-dimensional hydraulic models such as SWMM are recognized as providing less accurate results when simulating non-confined flows involving considerable lateral dispersion (VOJINOVIC; TUTULIC, 2009; FRAGA; CEA; PUERTAS, 2017). It is believed, therefore, that the simulation of the channel overflow events could be better represented in $1 \mathrm{D} / 2 \mathrm{D}$ hybrid hydraulic models if flooded area data are available.

\section{CONCLUSION}

This article proposed a methodology for constructing a Flood Hazard Chart that relates precipitation height and duration to the possibility of overflow occurrence in a stream section. For the development of this Flood Hazard Chart, it was necessary to determine the soil type and land use of the watershed, drainage network data, and a local IDF equation. In addition, to calibrate and validate the hydrological-hydraulic model and to assess the 
proposed chart, data related to the precipitation over the watershed and corresponding stream water level were necessary.

The methodology for the urban Flood Hazard Chart construction proposed in this research proved to be feasible. The results indicate that the hydrological-hydraulic model of the Cachoeirinha Watershed was able to reproduce $83 \%$ of the generated warnings. However, due to the limitations discussed in this paper, the model was not able to accurately represent the most intense rain events that generated orange and red warnings.

To increase confidence in the forecasts made through the proposed cachoeirinha's flood hazard chart, the assessment of the performance of other hydrological-hydraulic models is recommended for future studies. In addition, the use of a larger number of rain events that generated orange and red warnings is recommended. the assessment of methodologies that consider the spatial-temporal variation of design storms can also add benefits to the methodology proposed.

In the case of fully urbanized watersheds such as the Cachoeirinha Watershed, the Flood Hazard Chart, based on weather information, would enable municipal managers and civil defense agencies to act in a preventive manner in a short amount of time. Anticipated evacuations of floodable areas could be achieved, as well as changes in local traffic and the transmission of warnings advising people to stay home or in their workplace during the storm. The Flood Hazard Chart also has the potential to provide managers with more assertiveness in their decisions concerning the deployment of forecasting systems and warning systems.

Thus, while respecting the aforementioned limitations, this methodology for constructing a Flood Hazard Chart is validated as a tool to be implemented in flood risk management in cities such as Belo Horizonte.

\section{ACKNOWLEDGEMENTS}

The authors acknowledge SUDECAP -Superintendência de Desenvolvimento da Capital, for their support and for providing data for this research. We also acknowledge Capes (Coordenação de Aperfeiçoamento de Pessoal de Nível Superior), CNPq (Conselho Nacional de Desenvolvimento Científico e Tecnológico), and Fapemig (Fundação de Amparo à Pesquisa do Estado de Minas Gerais). We thank Flavio Fantini for assisting with the English translation of this paper.

\section{REFERENCES}

BARCO, J.; WONG, K. M.; STENSTROM, M. K. Automatic calibration of the U. S. EPA SWMM model for a large urban catchment. Journal of Hydraulic Engineering, v. 134, n. 4, p. 466-474, 2008. http://dx.doi.org/10.1061/(ASCE)0733-9429(2008)134:4(466).

BECK, N. G.; CONLEY, G.; KANNER, L.; MATHIAS, M. An urban runoff model designed to inform stormwater management decisions. Journal of Environmental Management, v. 193, p. 257269, 2017. http://dx.doi.org/10.1016/j.jenvman.2017.02.007. PMid:28226262.
BELO HORIZONTE. Prefeitura Municipal. Plano Diretor de Drenagem Urbana de Belo Horizonte. Belo Horizonte: PBH, 2000.

BELO HORIZONTE. Prefeitura Municipal. Monitoramento hidrológico bacias Arrudas e Onça: estabelecimento de curvas-chave. Belo Horizonte: PBH, 2010. Relatório.

BELO HORIZONTE. Prefeitura Municipal. Consolidação do diagnóstico das enchentes na bacia do Córrego Cachoeirinha e dos Ribeirões Pampulha e da Onça. Belo Horizonte: PBH, 2011. v. 1. Relatório.

BELO HORIZONTE. Prefeitura Municipal. Plano municipal de saneamento de Belo Horizonte. Belo Horizonte: PBH, 2016. Available from: < https://prefeitura.pbh.gov.br/sites/default/files/estruturade-governo/obras-e-iinfraestrutura/2018/documentos/volumei_ final_pms2016_2019_agosto.pdf>. Access on: 17 june 2018.

BENNETT, N. D.; CROKE, B. F. W.; GUARISO, G.; GUILLAUME, J. H. A.; HAMILTON, S. H.; JAKEMAN, A. J.; MARSILILIBELLI, S.; NEWHAM, L. T. H.; NORTON, J. P.; PERRIN, C.; PIERCE, S. A.; ROBSON, B.; SEPPELT, R.; VOINOV, A. A.; FATH, B. D.; ANDREASSIAN, V. Characterising performance of environmental models. Environmental Modelling \& Software, v. 40, p. 1-20, 2013. http://dx.doi.org/10.1016/j.envsoft.2012.09.011.

BOOTH, D. B.; JACKSON, C. R. Urbanization of aquatic systems: degradation thresholds, stormwater detection, and the limits of mitigation. Journal of the American Water Resources Association, v. 33, n. 5, p. 1077-1090, 1997. http://dx.doi.org/10.1111/j.1752-1688.1997. tb04126.x.

BRANDÃO, C.; RODRIGUES, R.; COSTA, J. P. Análise de fenómenos extremos precipitações intensas em Portugal continental. Lisboa: Direção dos Serviços de Recursos Hídricos, Instituto da Água, 2001. 57 p.

CHOW, V. T.; MAIDMENT, D. R.; MAYS, L. W. Applied hydrology. New York: McGraw-Hill, 1988. 572 p.

COLLISCHONN, W. Simulação bidrológica em grandes bacias. 2011. 270 f. Tese (Doutorado em Engenharia Civil) - Instituto de Pesquisas Hidráulicas, Universidade Federal do Rio Grande do Sul, Porto Alegre, 2001.

DJORDJEVIĆ, S.; PRODANOVIĆ, D.; WALTERS, G. A. Simulation of transcritical flow in pipe/channel networks. Journal of Hydraulic Engineering, v. 130, n. 12, p. 1167-1178, 2004. http:/ / dx.doi.org/10.1061/(ASCE)0733-9429(2004)130:12(1167).

DOTTORI, F.; SALAMON, P.; BIANCHI, A.; ALFIERI, L.; HIRPA, F. A.; FEYEN, L. Advances in water resources development and evaluation of a framework for global flood hazard mapping. Advances in Water Resources, v. 94, p. 87-102, 2016. http://dx.doi. org/10.1016/j.advwatres.2016.05.002.

FLETCHER, T. D.; ANDRIEU, H.; HAMEL, P. Understanding, management and modelling of urban hydrology and its consequences for receiving waters: a state of the art. Advances in 
Water Resources, v. 51, p. 261-279, 2013. http://dx.doi.org/10.1016/j. advwatres.2012.09.001.

FRAGA, I.; CEA, L.; PUERTAS, J. Validation of a 1D-2D dual drainage model under unsteady part-full and surcharged sewer conditions. Urban Water Journal, v. 14, n. 1, p. 74-84, 2017. http:/ / dx.doi.org/10.1080/1573062X.2015.1057180.

GUIMARÃES, M.; NAGHETTTINI, M. Análise regional da frequência e distribuição temporal das tempestades na região metropolitana de Belo Horizonte - RMBH. Revista Brasileira de Recursos Hidricos., v. 3, n. 4, p. 73-88, 1998. http://dx.doi.org/10.21168/ rbrh.v3n4.p73-88.

HUFF, F. A. Time distribution rainall in heavy storms. Water Resources Research, v. 3, n. 4, p. 1007-1019, 1967. http://dx.doi. org/10.1029/WR003i004p01007.

JIA, S.; LI, Y.; LÜ, A.; LIU, W.; ZHU, W.; YAN, J.; LIANG, Y.; XIANG, X.; GUAN, Z. City storm-flood events in China, 19842015. International Journal of Water Resources Development, v. 34, n. 4, p. 547-565, 2018.

JIANG, L.; CHEN, Y.; WANG, H. Urban flood simulation based on the SWMM model. LAHS-AISH Proceedings and Reports, v. 368, p. 186-191, 2015. http://dx.doi.org/10.5194/piahs-368-186-2015.

LEE, J. G.; HEANEY, J. P. Estimation of Urban Imperviousness and its Impacts on Storm Water Systems. Journal of Water Resources Planning and Management, v. 129, n. 5, p. 419-426, 2003. http:// dx.doi.org/10.1061/(ASCE)0733-9496(2003)129:5(419).

LENHS - LABORATÓRIO DE EFICIÊNCIA ENERGÉTICA E HIDRÁULICA EM SANEAMENTO. Manual do usuário EPA SWMM 5.0. João Pessoa: UFPB, 2012. Available from: < http:// www.lenhs.ct.ufpb.br/html/downloads/swmm/SWMM_2012. pdf $>$. Access on: 3 sept. 2015.

LIMA, A. P.; AMORIM, M. C. C. T. Análise de episódios de alagamentos e inundações urbanas na cidade de São Carlos a partir de notícias de jornal. Revista Brasileira de Climatologia, v. 15, p. 182-204, 2014.

LOUCKS, D. P.; VAN BEEK, E. Water resources systems planning and management: an introduction to methods, models and applications. Paris: UNESCO Publishing, 2005. (Studies and Reports in Hydrology).

MELLER, A.; PAIVA, E. Simulação hidrodinâmica 1D de inundações em sistemas de drenagem urbana. Revista Brasileira de Recursos Hídricos, v. 12, n. 2, p. 81-97, 2007. http://dx.doi. org/10.21168/rbrh.v12n2.p81-92.

MELO, N. I.; MOURA, P. M.; AGUIAR, I. M. C. Verificação da avaliação da estimativa de área impermeável do município de Belo Horizonte. Belo Horizonte: Departamento de Engenharia Hidráulica e Recursos Hídricos, Escola de Engenharia, Universidade Federal de Minas Gerais, 2014.
MENEZES FILHO, F. C. M.; AMARAL, D. B. Histórico da expansão urbana e ocorrência de inundações na cidade de CuiabáMT. Sociedade \& Natureza, v. 26, n. 1, p. 159-170, 2014. http:// dx.doi.org/10.1590/1982-451320140111.

MONTEIRO, L. R.; KOBIYAMA, M. Influências da distribuição temporal de precipitação no mapeamento de inundação. Revista de Gestão de Água da América Latina, v. 11, n. 2, p. 25-35, 2014. http:/ / dx.doi.org/10.21168/rega.v11n2.p25-35.

NIAZI, M.; NIETCH, C.; MAGHREBI, M.; JACKSON, N.; BENNETT, B. R.; TRYBY, M.; MASSOUDIEH, A. Storm water management model: performance review and gap analysis. Journal of Sustainable Water in the Built Environment, v. 3, n. 2, p. 04017002 , 2017. http://dx.doi.org/10.1061/JSWBAY.0000817.

NRCS - NATURAL RESOURCES CONSERVATION SERVICE. United States Department of Agriculture. Estimation of direct runoff from storm rainfall. Part 630: hydrology. In: U.S. DEPARTMENT OF AGRICULTURE - USDA. National engineering handbook. Washington: USDA, 2004. cap. 10.

PFANNERSTILL, M.; GUSE, B.; FOHRER, N. Smart low flow signature metrics for an improved overall performance evaluation of hydrological models. Journal of Hydrology, v. 510, p. 447-458, 2014. http://dx.doi.org/10.1016/j.jhydrol.2013.12.044.

PONCE, V. M.; HAWKINS, R. H. Runoff curve number: has it reached maturity? Journal of Hydrologic Engineering, v. 1, n. 1, p. 11-19, 1996. http://dx.doi.org/10.1061/(ASCE)1084-0699(1996)1:1(11).

RAMOS, M. H. D. Drenagem urbana: aspectos urbanísticos, legais e metodológicos em Belo Horizonte. 1998. 103 f. Dissertação (Mestrado em Saneamento, Meio Ambiente e Recursos Hídricos) - Escola de Engenharia. Universidade Federal de Minas Gerais, Belo Horizonte, 1998.

RENÉ, J.-R.; DJORDJEVIĆ, S.; BUTLER, D.; MADSEN, H.; MARK, O. Assessing the potential for real-time urban flood forecasting based on a worldwide survey on data availability. Urban Water Journal, v. 11, n. 7, p. 573-583, 2014. http://dx.doi.org/10. 1080/1573062X.2013.795237.

ROSSMAN, L. A. SWMM (stormwater management model), version 5: user manual. Washington: Environmental Protection Agency, 2004.

SALVADORE, E.; BRONDERS, J.; BATELAAN, O. Hydrological modelling of urbanized catchments: a review and future directions. Journal of Hydrology, v. 529, p. 62-81, 2015. http://dx.doi.org/10.1016/j. jhydrol.2015.06.028.

SAYERS, P. B.; HALL, J. W.; MEADOWCROFT, I. C. Towards risk-based flood hazard management in the UK. ICE Journal of Civil Engineering, v. 150, n. 5, p. 36-42, 2002. http://dx.doi. org/10.1680/cien.2002.150.5.36. 
SAYERS, P. L. I. Y.; GALLOWAY, G.; PENNING-ROWSELL, E.; SHEN, F.; WEN, K.; CHEN, Y.; LE QUESNE, T. Flood risk management. a strategic approach. Paris: UNESCO, 2013.

SAYERS, P.; GALLOWAY, G.; PENNING-ROWSELL, E.; YUANYUAN, L.; FUXIN, S.; YIWEI, C.; KANG, W.; LE QUESNE, T.; WANG, L.; GUAN, Y. Strategic flood management: ten 'golden rules' to guide a sound approach. International Journal of River Basin Management, v. 13, n. 2, p. 137-151, 2015. http:/ / dx.doi.org/10.1080/15715124.2014.902378.

SILVA, A. B.; CARVALHO, E. T.; FANTINEL, L. M.; ROMANO, A. W.; VIANA, C. S. Estudos geológicos, hidrogeológicos, geotécnicos e geoambientais integrados no município de Belo Horizonte: projeto estudos técnicos para o levantamento da carta geológica do município de Belo Horizonte. Belo Horizonte: Prefeitura de Belo Horizonte, UFMG, Instituto de Geociências, 1995.

SILVA, T. F. G.; VINÇON-LEITE, B.; GIANI, A.; FIGUEREDO, C. C.; PETRUCCI, G.; LEMAIRE, B.; SPERLING, E. V.; TASSIN, B.; SEIDL, M.; KHAC, V. T.; VIANA, P. S.; VIANA, V. F. L.; TOSCANO, R. A.; RODRIGUES, B. H. M.; NASCIMENTO, N. O. Modelagem da Lagoa da Pampulha: uma ferramenta para avaliar o impacto da bacia hidrográfica na dinâmica do fitoplâncton. Revista Engenharia Sanitária Ambiental, v. 21, n. 1, p. 95-108, 2016. http://dx.doi.org/10.1590/S1413-41520201600100125692.

SILVA, T.; VIÇON-LEITE, B.; PETRUCCI, G.; NASCIMENTO, N. Monitoramento e modelagem da qualidade da água do escoamento superficial nas bacias dos córregos Ressaca e Sarandi (Minas Gerais, Brasil). In: POLETO, C.; SILVEIRA, A. L. L.; CARDOSO, A.; GOLDENFUM, J. A.; DORNELLES, F; TASSI, R.; MOURA, P. M. (Orgs.). Águas urbanas. Porto Alegre: ABRH, 2015. v. 1.

SINGH, V. P. SCS-CN method revisited using entropy theory. Transactions of the ASABE, v. 56, n. 5, p. 1805-1820, 2013.

SOUZA, R. M. P.; CRISPIM, D. C.; FORMIGA, K. T. M. Estudo comparativo ente os modelos SWMM e HEC-HMS para simulação de escoamento superficial: caso de estudo da bacia do córrego Samambaia. Revista Eletrônica de Engenharia Civil, v. 5, n. 2, p. 20-30, 2012.

SZEWRAŃSKI, S.; CHRUŚCIŃSKI, J.; KAZAK, J.; ŚWIĄDER, M.; TOKARCZYK-DOROCIAK, K.; ŻMUDA, R. Pluvial Flood Risk Assessment Tool (PFRA) for rainwater management and adaptation to climate change in newly urbanised areas. Water, v. 10, n. 4, p. 1-20, 2018. http://dx.doi.org/10.3390/w10040386.

TEIXEIRA, M. L. C. Estimativa de área impermeável do município de Belo Horizonte. Belo Horizonte: Departamento de Hidráulica e Recursos Hídricos, Escola de Engenharia, Universidade Federal de Minas Gerais, 2013. Relatório final.
TUCCI, C. E. M. Modelos hidrológicos. Porto Alegre: ABRH, 2005. 680 p.

TUCCI, C. E. M. Hidrologia: ciência e aplicação. 4. ed. Porto Alegre: ABRH, 2007. 943 p.

TUCCI, C. E. M.; BRAGA, B. Clima e recursos hídricos. In: TUCCI, C. E. M.; BRAGA, B. (Orgs.). Clima e recursos hídricos no Brasil. Porto Alegre: ABRH, 2003. cap. 1, p. 1-22.

TUCCI, C.; COLLISCHONN, M. Ajuste multiobjetivo dos parâmetros de um modelo hidrológico. Revista Brasileira de Recursos Hidricos, v. 8, n. 3, p. 27-39, 2003. http://dx.doi.org/10.21168/ rbrh.v8n3.p27-39.

TUCCI, C.; CRUZ, M. Avaliação dos cenários de planejamento na drenagem urbana. Revista Brasileira de Recursos Hidricos, v. 13, n. 3, p. 59-71, 2008. http://dx.doi.org/10.21168/rbrh.v13n3.p59-71.

VOJINOVIC, Z.; TUTULIC, D. On the use of 1D and coupled 1D-2D modelling approaches for assessment of flood damage in urban areas. Urban Water Journal, v. 6, n. 3, p. 183-199, 2009. http://dx.doi.org/10.1080/15730620802566877.

WRI - WORLD RESOURCES INSTITUTE. World's 15 countries with the most people exposed to river floods. Washington, 2015. Available from: <www.wri.org/blog/2015/03/world \%E2\%80\%99s-15countries-most-people-exposed-river-floods $>$. Access on: 1 mar. 2017.

ZANANDREA, F; SILVEIRA, A. L. L. Effects of LID implementation on hydrological processes in an urban catchment under consolidation in Brazil. Journal of Environmental Engineering, v. 144, n. 9, p. 04018072, 2018. http://dx.doi.org/10.1061/(ASCE) EE.1943-7870.0001417.

ZOPPOU, C. Review of urban storm water models. Environmental Modelling \& Software, v. 16, n. 3, p. 195-231, 2001. http://dx.doi. org/10.1016/S1364-8152(00)00084-0.

\section{Authors contributions}

Rejane Cristina Siqueira: Conducted the modeling and data analysis.

Priscilla Macedo Moura: Conceived the methodology.

Talita Fernanda das Graças Silva: Gave support regarding the theoretical background on the hydrological model.

All authors wrote the manuscript and contributed to the discussion of the results and the revision of the manuscript. 